\section{Meiotic Defects and Premature Tapetal Degeneration Are Involved in the Low Fertility of Oncidesa Gower Ramsey, an Important Cut-flower Orchid}

\author{
Cheng-Jung Hu \\ Pingtung Seed and Seedling Research Center, Taiwan Seed Improvement and \\ Propagation Station, Council of Agriculture, Executive Yuan, 90943 \\ Pingtung, Taiwan, R.O.C.
}

Nean Lee

Department of Horticulture and Landscape Architecture, National Taiwan University, 10617 Taipei, Taiwan, R.O.C.

Yung-I Lee ${ }^{1}$

Biology Department, National Museum of Natural Science, 40453 Taichung, Taiwan, R.O.C.; and Department of Life Sciences, National Chung Hsing University, 40227 Taichung, Taiwan, R.O.C.

Additional index words. fertility, histology, Oncidesa, pollen development, pollen germination, pollinia, sporad

\begin{abstract}
The dancing-lady orchid, Oncidesa Gower Ramsey, is an important cultivar for cut-flower production, but it has low pollen fertility in breeding programs. In this study, we compared the pollen germination in vitro, sporad type, and pollinia development of Oncsa. Gower Ramsey and a diploid species, Oncidium sphacelatum Lindl (one of its grandparents). In Oncsa. Gower Ramsey, the pollen germination in vitro was lower as compared with those in Onc. sphacelatum. In addition, the frequency of abnormal sporads in Oncsa. Gower Ramsey was higher than those in Onc. sphacelatum. In Oncsa. Gower Ramsey, the middle layer and the tapetum were disorganized before meiosis, and subsequently they degenerated at the early tetrad stage. In contrast, the middle layer and the tapetum of Onc. sphacelatum began to degenerate at the early tetrad stage and fully disappeared at the bicellular pollen stage. These results suggested that the abnormal meiosis caused by unbalanced genomes and the premature degeneration of the middle layer and the tapetum could probably result in the abnormal pollen development and the low fertility of Oncsa. Gower Ramsey.
\end{abstract}

The dancing-lady orchid, Oncidium Sw., and its relative genera within subtribe Oncidiinae native to Central and South America are important ornamental orchids in the horticultural market (Chase, 1997). Because of the long-lasting and bright yellow flowers, the cultivars of intergeneric hybrid Oncidesa (Oncidium $\times$ Gomesa $\mathrm{R}$. Br.), for example, Oncsa. Gower Ramsey and Oncsa. Goldiana, are excellent cut-flower materials for decoration in flower arrangements. In Taiwan, Oncsa. Gower Ramsey has been an important cultivar for cut-flower production over the past few decades. The creation of new cultivars to meet the requirements of the floral

\footnotetext{
Received for publication 26 Feb. 2018. Accepted for publication 28 Mar. 2018

This work was supported by grants from National Museum of Natural Science, Taiwan, R.O.C., to Yung-I Lee, and the grant from Council of Agriculture, Executive Yuan, R.O.C., to Cheng-Jung $\mathrm{Hu}$.

${ }^{1}$ Corresponding author. E-mail: leeyungi@hotmail. com or leeyungi@mail.nmns.edu.tw.
} pollination experiments.

The causes of low fertility may be associated with abnormal meiosis in orchid hybrids. Meiotic irregularities, such as univalents, trivalents, chromosome bridges, and lagging chromosomes, are observed commonly in the interspecific or intergeneric hybrids of Aranda (Lee, 1987), Dendrobium Lindl. (Kamemoto et al., 1999), Doritaenopsis (Bolanos-Villegas et al., 2008), and Paphiopedilum Pfitz. (Lee et al., 2011), and the irregular meiotic pairing subsequently causes the formation of abnormal sporad types. In addition, it is possible that male sterility or low fertility is related to the malfunction of anther tissue. The sporophytic anther tissues play important roles in pollen development, not only by providing physical support but also by supplying signals and materials necessary for pollen development. Especially, the tapetum, the most inner somatic cell layer of the anther locule, plays an essential role in pollen development. Tapetum secrets enzymes for the release of microspores from tetrads and provides nutrients and pollen wall materials required for pollen development and maturation (Goldberg et al., 1993; Hegde and Rudramuniyappa, 1986; Wilson and Yang, 2004). It has been observed that the abnormal development or dysfunction of tapetum may lead to the pollen degeneration in a number of plants, for example, Arabidopsis thaliana (L.) Heynh (Kim et al., 2010), garlic (Shemesh-Mayer et al., 2015), kiwifruit (Giuseppina et al., 2013), tomato (Jeong et al., 2014), Solanum Lindl. (Conicella et al., 1997), snap bean (Suzuki et al., 2001), petunia (Kapoor et al., 2002), radish (Shi et al., 2010), and rice (Ku et al., 2003; Shi et al., 2009).

The pollinia development of orchids has been reported in Calanthe Lindl. (Hegde and Rudramuniyappa, 1986), Epidendrum Lindl. (Yeung, 1987; Yeung and Blackman, 1983), Zeuxine Lindl. (Vijayaraghavan et al., 1987), Peristylus Lindl. (Zee and Siu, 1990), Aranda (Lee, 1987), and some intergeneric hybrids, for example, Cattleya Lindl., Laelia Lindl., and Brassavola Lindl. (Stort, 1984). However, limited information is available about the pollinia development of Oncidesa, and there are no reports about the possible roles of anther tissues in relation to the male sterility or low fertility. Histological study on pollinia development is required to provide the necessary background information before embarking on breeding programs. To get a better understanding of the low fertility in Oncsa. Gower Ramsey as the pollen parent, we compared the pollinia development of Oncsa. Gower Ramsey and its diploid parental species, Onc. sphacelatum (with good fertility). In addition, their sporad types after meiosis, pollen viability, and capsule setting by cross-pollination also were examined. The present study provides detailed information of the pollinia development at the light microscope level and extends our knowledge concerning pollen development in Oncidesa.

\section{Materials and Methods}

Plant material. Mature plants of Onc. sphacelatum and Oncsa. Gower Ramsey were cultivated in the greenhouse of Botanical Garden of National Museum of Natural Science, Taiwan. Plants were grown in pine bark medium (Orchiata; Besgrow, Christchurch, New Zealand) under 50\% shade. Plants were fertigated monthly with a $20 \mathrm{~N}$ 20P-20K Peters Professional 20-20-20 general purpose fertilizer (Scotts, Marysville, $\mathrm{OH})$ at $0.5 \mathrm{~g} \cdot \mathrm{L}^{-1}$. For histological and sporad type studies, developing flower buds of different stages were collected at 3-d intervals until anthesis. More than 100 developing 
flower buds and flowers were collected for this study.

Light microscopy. Developing flower buds were collected and fixed in $2.5 \%$ glutaraldehyde (Electron Microscopy Sciences, Hatfield, PA) buffered with 0.1 m sodium phosphate buffer, $\mathrm{pH} 6.8$, at $4{ }^{\circ} \mathrm{C}$ overnight. After three 15-min buffer rinses, the materials were postfixed in $1 \% \mathrm{OsO}_{4}$ (Electron Microscopy Sciences) in the same buffer for $4 \mathrm{~h}$ at room temperature, then rinsed in three 15 min changes of buffer. Following fixation, the materials were dehydrated in an acetone series (Merck KGaA, Darmstadt, Germany), and embedded in Spurr's resin (Electron Microscopy Sciences). Serial sections $1 \mu \mathrm{m}$ thick were cut, using a diamond knife, on an ultramicrotome (Ultracut E; Reichert-Jung, Vienna, Austria). These sections were stained with $0.1 \%(\mathrm{w} / \mathrm{v})$ toluidine blue $\mathrm{O}$ in benzoate buffer for general histology. The sections were viewed and the images were captured digitally using a charge-coupled device camera attached to a light microscope (Axioskop 2; Carl Zeiss AG, Jena, Germany).

Sporad type observation. At anthesis, the pollinia were collected and fixed in fresh prepared Farmer's fluid (three parts of ethanol to one part of glacial acetic acid). The pollinia were macerated with $6 \%$ cellulose (Onozuka R-10; Yakult Honsha, Japan) and $6 \%$ pectinase (Sigma-Aldrich Co., St. Louis, $\mathrm{MO}$ ) in $75 \mathrm{~mm} \mathrm{KCl}, \mathrm{pH} 4.0$, at $37{ }^{\circ} \mathrm{C}$ for $90 \mathrm{~min}$ and squashed on slides with the same fixative. After drying, the slides were stained with 4',6-diamidino-2-phenylindole in VECTASHIELD (Vector Laboratories Inc., Burlingame, CA), and the images were captured digitally by a charge-coupled device camera attached to an epifluorescence microscope (Axioskop 2; Carl Zeiss AG).

In vitro pollen germination. At the time of anthesis, pollinia were collected from the flowers of Onc. sphacelatum and Oncsa. Gower Ramsey. After removing anther caps, the surface of pollinia was wiped with cotton soaked with $70 \%$ ethanol solution. In the laminar flow hood, six pollinia mass were transferred to one petri dish containing $15 \mathrm{~mL}$ of germination medium. The germination medium used in this study was the modified Brewbaker and Kwack medium (Brewbaker and Kwack, 1963), containing $20 \mathrm{~g} \cdot \mathrm{L}^{-1}$ sucrose, $100 \mathrm{mg} \cdot \mathrm{L}^{-1} \quad \mathrm{H}_{3} \mathrm{BO}_{3}, 200 \mathrm{mg} \cdot \mathrm{L}^{-1}$ $\mathrm{MgSO}_{4} \cdot 7 \mathrm{H}_{2} \mathrm{O}, 300 \mathrm{mg} \cdot \mathrm{L}^{-1} \mathrm{Ca}\left(\mathrm{NO}_{3}\right)_{2} \cdot 4 \mathrm{H}_{2} \mathrm{O}$, $100 \mathrm{mg} \cdot \mathrm{L}^{-1} \mathrm{KNO}_{3}$, and solidified with 10 g. $\mathrm{L}^{-1}$ agar (Sigma-Aldrich Co.). The $\mathrm{pH}$ value was adjusted to 5.5 with $1 \mathrm{~N} \mathrm{NaOH}$ solution before autoclaving at $121{ }^{\circ} \mathrm{C}$ for 15 min. The cultures were maintained at $25 \pm$ $1{ }^{\circ} \mathrm{C}$ in the dark chamber, and the pollinia were taken out for observation at 1, 2, 4, 6, 8, and $10 \mathrm{~d}$ of culture. The germinating pollinia were transferred onto slides and gently separated by forceps, then were stained with $0.04 \%$ methyl green (Sigma-Aldrich Co.) for pollen tube observation under a light microscopy. Germination of pollen was defined as emergence of the pollen tube from the pollen grain. The germination percentage was evaluated as the percentage of the number of pollen grains germinated among the total countered number of pollen grains. Experiments were performed in a randomized design.

Capsule setting by cross-pollination. For cross-pollination experiments, Oncsa. Gower Ramsey was cross-pollinated with Onc. sphacelatum or Gom. Java, respectively. The reciprocal crosses were made at the same time. The flowers were labeled and manually cross-pollinated by transferring pollinia from the male parent onto the stigma of the female parent as soon as they opened. The capsule setting was calculated 2 months after crosspollination.

\section{Results}

The pollen germination in vitro. In Onc. sphacelatum, the pollen tube began to grow by $2 \mathrm{~d}$ after culture, whereas in Oncsa. Gower
Ramsey, the pollen tube began to grow by $6 \mathrm{~d}$ after culture. By $10 \mathrm{~d}$ after culture, the percentage of pollen germination in vitro in Onc. sphacelatum was much greater $(68.29 \pm$ $5.21 \%$ ) as compared with those in Oncsa. Gower Ramsey $(2.30 \pm 1.39 \%)$ (Table 3).

The pollen development. In Onc. sphacelatum and Oncsa. Gower Ramsey, at the early sporogenous stage, the sporogenous cells had nuclei of great volume with conspicuous nucleoli and the dense cytoplasm (Fig. 1A and B). The primary parietal layer underwent periclinal divisions, giving rise to multilayered microsporangial walls that differentiated into the endothecium, the middle layer, and the tapetum (Fig. 1C and D). The sporogenous cells gave rise to form microspore mother cells (MMCs) that were filled with numerous small vacuoles (Fig. $1 \mathrm{C}$ and D). The endothecial cells continued to enlarge by

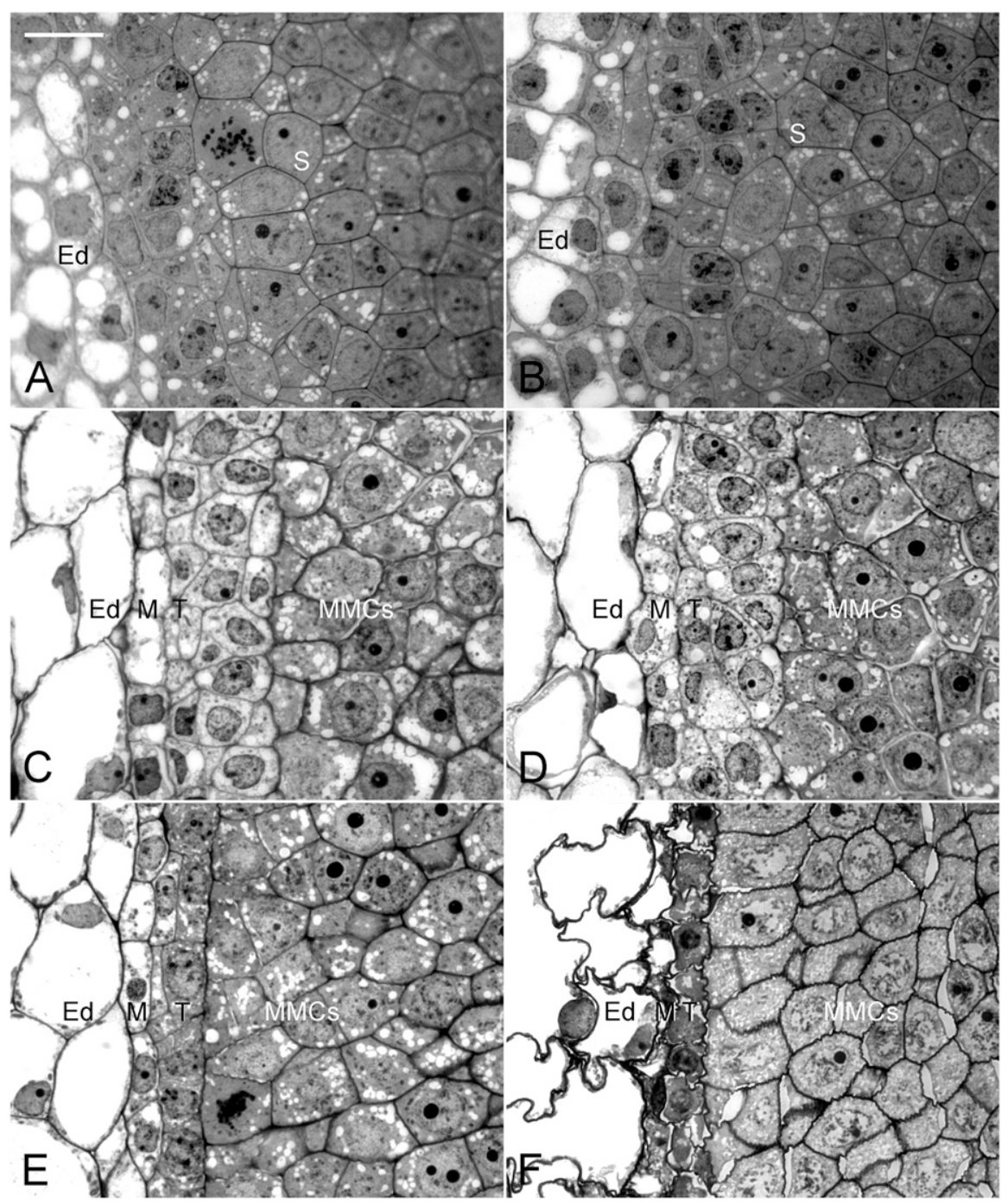

Fig. 1. Micrographs of the microspore mother cell (MMC) development of Onc. sphacelatum and Oncsa. Gower Ramsey. In (A) Onc. sphacelatum and (B) Oncsa. Gower Ramsey, their sporogenous cells (S) have dense cytoplasms with nuclei of great volume. Cell divisions in the primary parietal layer give rise to multilayered microsporangial walls that differentiate into the endothecium (Ed), the middle layer (M), and the tapetum (T) in (C) Onc. sphacelatum and (D) Oncsa. Gower Ramsey, and the sporogenous cells give rise to form MMCs. In Onc. sphacelatum (E), the chromatins of MMCs further condense in preparation for meiotic divisions, and the tapetal cells have elongated and possess prominent nuclei, whereas in Oncsa. Gower Ramsey (F), the cells of the middle layer and the tapetum are disorganized with the appearance of condensed nuclei. Scale bar $=10 \mu \mathrm{m}$. 
the process of vacuolation, whereas the cells of the middle layer and the tapetum remained cytoplasmic. Before meiosis, in Onc. sphacelatum, the tapetal cells were elongated and possessed prominent nuclei (Fig. 1E). In MMCs, the chromatins further condensed in preparation for meiotic divisions (Fig. 1E). On the contrary, in Oncsa. Gower Ramsey, the cells of the middle layer and the tapetum were disorganized with the appearance of condensed nuclei (Fig. 1F). In Onc. sphacelatum and Oncsa. Gower Ramsey, MMCs underwent meiotic divisions and resulted in the formation of microspore tetrads (Fig. 2A and B). In Onc. sphacelatum, the middle layer and the tapetum began to degenerate after meiosis (Fig. 2A). In Onc. sphacelatum and Oncsa. Gower Ramsey, haploid microspores were not released from tetrads after meiosis, and all tetrads aggregated to form the pollinium. The microspore within a tetrad underwent pollen mitosis I (Fig. 2A), giving rise to a vegetative cell and a generative cell (Fig. 2C and D). At anthesis, the mature pollen tetrads within a pollinium of Onc. sphacelatum contained numerous lipid bodies and protein bodies (Fig. 2E), whereas in Oncsa. Gower Ramsey, a number of mature pollen tetrads shrank and degenerated (Fig. 2F).

Sporad type observation. Following the process of meiosis, each PMC normally produced a tetrad with four microspores in Onc. sphacelatum (Fig. 3A), whereas in Oncsa. Gower Ramsey, a considerable number of irregular sporad types were observed (Fig. 3B-D). In Onc. sphacelatum, 85.8\% of normal tetrads were formed, whereas in Oncsa. Gower Ramsey, only $59.8 \%$ of normal tetrads were formed (Table 1). The frequency of abnormal sporads (e.g., dyad, triad, and sporads with micronuclei) in Oncsa. Gower Ramsey (40.2\%) was higher than those in Onc. sphacelatum (14.2\%).

Capsule setting by cross-pollination. Capsule setting of $55 \%$ and $81.3 \%$, respectively, was observed when Oncsa. Gower Ramsey was used as the female parent and Onc. sphacelatum and Gom. Java as the male parent. No capsule setting was observed when Oncsa. Gower Ramsey was used as the male parent and Onc. sphacelatum and Gom. Java as the female parent (Table 2).

\section{Discussion}

In this study, as compared with Onc. sphacelatum, the lower pollen viability and the higher abnormal sporads observed in Oncsa. Gower Ramsey (Tables 1 and 3) may be attributed to the irregularity of meiotic pairing. Oncsa. Gower Ramsey is an intergeneric hybrid that comprises three species, i.e., Onc. sphacelatum $(2 n=56)$, Gom. flexuosa (Lodd.) M.W. Chase \& N.H. Williams Sims $(2 n=56)$, and Gom. varicosa (Lindl.) M.W. Chase \& N.H. Williams ( $2 n=$ 112) (Felix and Guerra, 2000), and the counts of chromosome number $2 n=$ ca. $75-83$ were observed in Oncsa. Gower Ramsey, suggesting a polyploid or aneuploid hybrid (Hu,
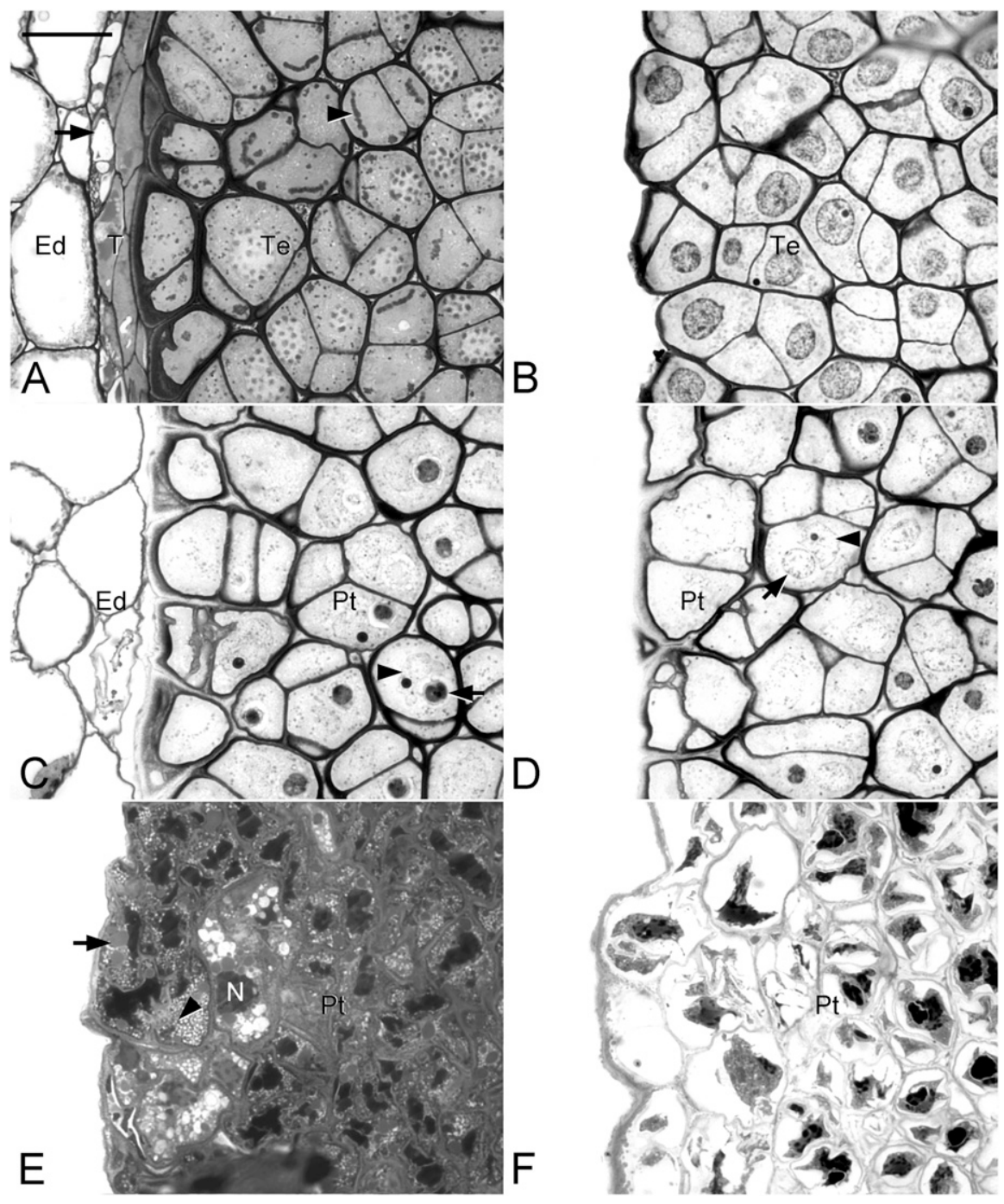

Fig. 2. Micrographs of the microgametogenesis of Onc. sphacelatum and Oncsa. Gower Ramsey. Meiotic divisions (arrowhead) result in the formation of microspore tetrads (Te). In Onc. sphacelatum (A), the cells of middle layer and the tapetum (arrow) have become compressed, whereas in Oncsa. Gower Ramsey (B) the cells of middle layer and the tapetum have degenerated during meiosis. The pollen tetrads (Pt) of (C) Onc. sphacelatum and (D) Oncsa. Gower Ramsey contain a vegetative cell (arrow) and a generative cell (arrowhead) after pollen mitosis I. At anthesis, the pollen tetrads of Onc. sphacelatum (E) contain numerous lipid bodies (arrow) and protein bodies, whereas in Oncsa. Gower Ramsey (F), most mature pollen tetrads $(\mathrm{Pt})$ have shrunk and degenerated. Scale bar $=10 \mu \mathrm{m} . \mathrm{N}=$ nucleus; Ed = endothecium.

2001). The degeneration of sporads with unbalanced genomes has been reported in a number of primary hybrids in Phalaenopsis Blume (Arends, 1970) and Paphiopedilum Lindl. (Lee et al., 2011). Lee (1987) examined the meiotic behaviors and the sporad formation of different clones of an intergeneric orchid hybrid, Aranda Lucky Laycock (Arachnis hookerana $\mathrm{Rchb} . \times$ Vanda tricolor Lind1.), and found that the fertile clones produced a higher frequency of dyads and tetrads without micronuclei, whereas the infertile clones produced more dyads and tetrads with micronuclei. Similarly, in Doritaenopsis orchids, the cultivars with high fertility were well correlated with the high frequency of normal tetrads (BolanosVillegas et al., 2008).

Like many orchids in the subfamily Epidendroideae, species within subtribe Oncidiinae have a compact pollinium that is composed of numerous tetrads (Pacini and Hesse, 2002). In our observations, at the time of anthesis, the pollinia within the anther locule of Oncsa. Gower Ramsey often appeared shriveled. To provide information about the pollinia abortion, histological studies were initiated to investigate the possible timing and tissues/cells involved in the abortion of pollinia during anther development. An interesting feature of this study revealed that the early degeneration of the middle layer and the tapetum may play an important role in the shriveled pollinia of Oncsa. Gower Ramsey. The tapetum is the innermost layer of the anther walls that contacts directly with the developing pollen and provides necessary nutrients and elements for pollen development and maturation (Pacini, 2010). In general, the tapetum begins to degenerate at the tetrad stage and is crushed completely by the bicellular pollen stage (Zhang et al., 2011) or 


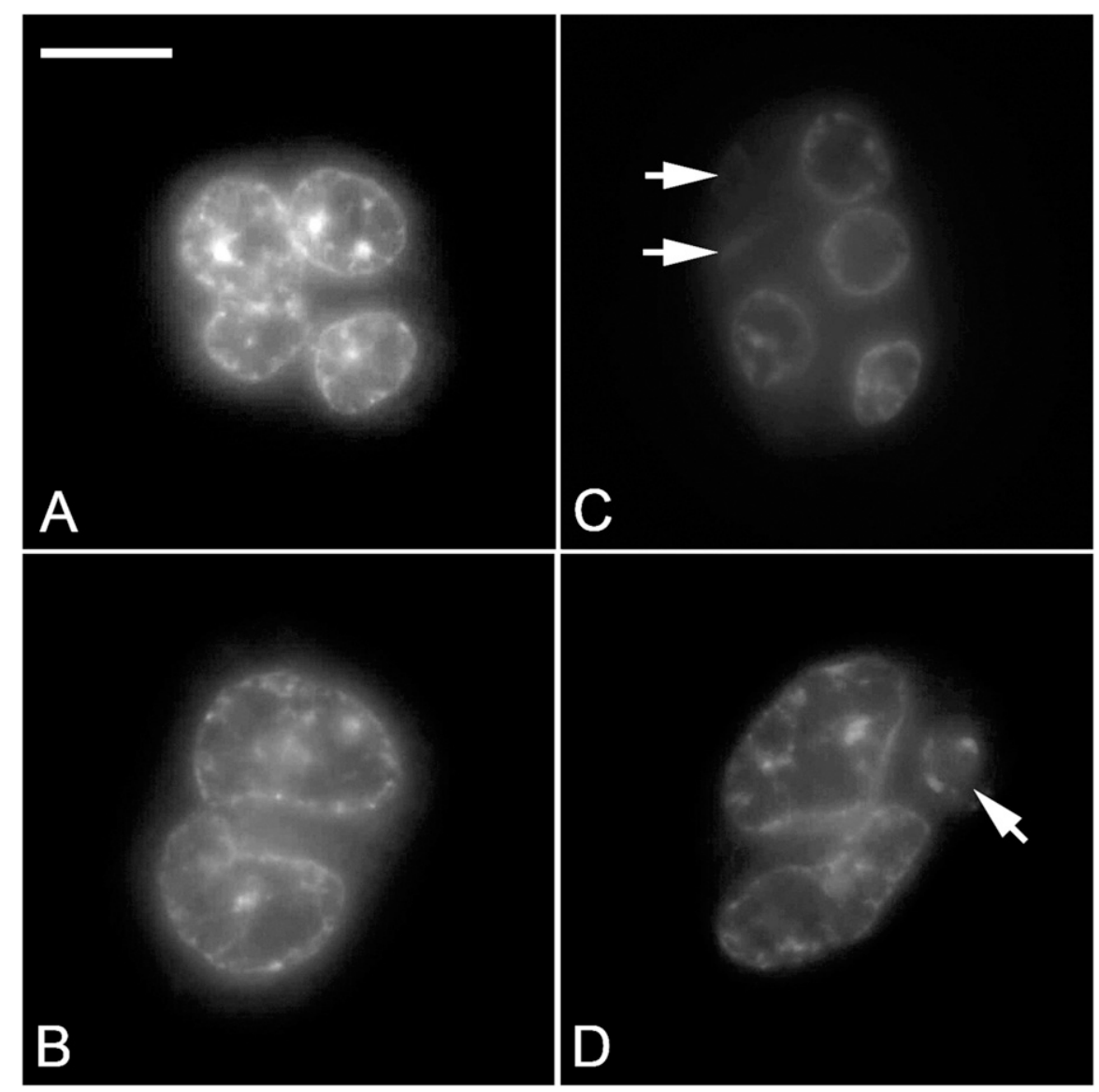

Fig. 3. The sporad type observation in Onc. sphacelatum and Oncsa. Gower Ramsey. The presence of nuclei is confirmed by the 4',6-diamidino-2-phenylindole stain when viewed with a fluorescence microscope. The normal tetrad (A) of Onc. sphacelatum, whereas a dyad (B), an irregular tetrad (C) with micronuclei (arrows), and a triad (D) containing two large nuclei and one small nucleus (arrow) are commonly observed in Oncsa. Gower Ramsey. Scale bar $=10 \mu \mathrm{m}$.

Table 1. The number and percentage of sporad type observed in Onc. sphacelatum and Oncsa. Gower Ramsey.

\begin{tabular}{lccccccc}
\hline \multicolumn{1}{c}{$\begin{array}{c}\text { No. of } \\
\text { sporad } \\
\text { observed }\end{array}$} & Dyad (\%) & Dyad $^{\mathrm{z}}(\%)$ & $\operatorname{Triad}^{(\%)}$ & Triad $^{\mathrm{z}}(\%)$ & Tetrad (\%) & Tetrad $^{\mathrm{z}}(\%)$ \\
Taxon & 225 & $18(8)^{\mathrm{y}}$ & $3(1.3)$ & $4(1.8)$ & $0(0)$ & $193(85.8)$ & $7(3.1)$ \\
\hline Onc. sphacelatum & 239 & $32(13.4)$ & $9(3.8)$ & $17(7.1)$ & $8(3.3)$ & $143(59.8)$ & $30(12.6)$ \\
$\begin{array}{l}\text { Oncsa. Gower } \\
\quad \text { Ramsey }\end{array}$ & & & & & & &
\end{tabular}

${ }^{\mathrm{z}}$ Sporads with micronucleus.

${ }^{\mathrm{y}}$ The data in bracket are percentages.

Table 2. Capsule setting of Oncsa. Gower Ramsey by cross-pollination.

\begin{tabular}{llcccc}
\hline \multicolumn{2}{c}{ Combinations } & \multicolumn{1}{c}{$\begin{array}{c}\text { No. of flower } \\
\text { pollinated }\end{array}$} & $\begin{array}{c}\text { No. of capsule } \\
\text { setting }\end{array}$ & $\begin{array}{c}\text { Capsule } \\
\text { setting (\%) }\end{array}$ \\
\hline Female & \multicolumn{1}{c}{ Oncsa. Gower Ramsey } & Onc. sphacelatum & 20 & 11 & 55 \\
Oncsa. Gower Ramsey & Gom. Java & 32 & 26 & 81.3 \\
Onc. sphacelatum & Oncsa. Gower Ramsey & 20 & 0 & 0 \\
Gom. Java & Oncsa. Gower Ramsey & 5 & 0 & 0 \\
\hline
\end{tabular}

Table 3. In vitro pollen germination of Onc. sphacelatum and Oncsa. Gower Ramsey. ${ }^{z}$

\begin{tabular}{lcccccc}
\hline & \multicolumn{5}{c}{ Germination (\%) } \\
\cline { 2 - 7 } & \multicolumn{5}{c}{ Days after culture } \\
\cline { 2 - 7 } Cultivar & 1 & 2 & 4 & 6 & 8 & 10 \\
\hline $\begin{array}{l}\text { Oncsa. Gower } \\
\text { Ramsey }\end{array}$ & $0.00 \pm 0.00$ & $0.00 \pm 0.00$ & $0.00 \pm 0.00$ & $0.01 \pm 0.004$ & $0.15 \pm 0.07$ & $2.30 \pm 1.39$ \\
Onc. sphacelatum & $0.00 \pm 0.00$ & $1.67 \pm 0.31$ & $24.02 \pm 2.97$ & $40.49 \pm 4.54$ & $58.49 \pm 6.18$ & $68.29 \pm 5.21$ \\
\hline
\end{tabular}

${ }^{\mathrm{z}}$ Data are mean \pm SE of four replicates and eight pollinia from four flowers for each. The pollinia were cultured in modified Brebaker and Kwack medium with 2\% sucrose and 1\% agar. the vacuolated microspore stage (Mizelle et al., 1989). Judging from our histological sections, the middle layer and the tapetum of Oncsa. Gower Ramsey became disorganized before meiosis (Fig. 1F). At the early tetrad stage, the middle layer and the tapetum of Oncsa. Gower Ramsey already disappeared (Fig. 2B). On the contrary, the middle layer and the tapetum of Onc. sphacelatum began to degenerate at the early tetrad stage (Fig. 2A) and fully disappeared at the bicellular pollen stage (Fig. 2C).

In our results of cross-pollination, $55 \%$ to $81.3 \%$ of capsule setting could be obtained when Oncsa. Gower Ramsey was used as the female parent, whereas no capsule setting could be observed when Oncsa. Gower Ramsey was used as the male parent (Table 2). It has been broadly reported that premature degeneration of tapetum usually causes male sterility. For example, in the somatic hybrids of Solanum commersonit Dun. and $S$. tuberosum Lindl., the early breakdown of tapetum and meiotic defects result in the male sterility (Conicella et al., 1997). In petunia, silencing of the tapetumspecific zinc finger gene may result in the precocious degeneration of tapetum and the subsequent pollen abortion (Kapoor et al., 2002). In the photoperiod-sensitive genic male sterility rice, the pollen abortion is associated with the premature degeneration of tapetum at the PMC stage (Shi et al., 2009). In snap bean, pollen sterility is caused by the premature degeneration of tapetum under the condition of high temperature (Suzuki et al., 2001). Tapetum is a shortlived cell layer of anther wall, and the progression of cell death in tapetum is an orderly and essential process for the normal pollen development, anther dehiscence, and pollen release and consequently guarantees the pollen fertility (Varnier et al., 2005; Wu and Cheung, 2000). The premature or delayed programmed cell death (PCD) of tapetum will result in the male sterility (Papini et al., 1999). In kiwifruit, male sterility was caused by a delayed PCD in the middle layer and tapetum (Giuseppina et al., 2013), whereas the premature PCD is detected in tapetum of the male-sterile lines of rice ( $\mathrm{Ku}$ et al., 2003) and sunflower (Balk and Leaver, 2001). In Oncsa. Gower Ramsey, the middle layer and the tapetum lost their regular cell shape before meiosis, then followed by cell condensation, which is similar to the progression of premature PCD in tapetum observed in the male-sterile lines of rice ( $\mathrm{Ku}$ et al., 2003). Further studies are needed to identify the possible role of PCD involved in the abnormal pollen development of Oncsa. Gower Ramsey.

In conclusion, we compared the ontogeny of the anther development in Oncsa. Gower Ramsey and the fertile diploid species, Onc. sphacelatum, and provide both the histological and cytological marks of the events causing the low fertility of Oncsa. Gower Ramsey. We propose that the abnormal meiosis caused by unbalanced genomes and the premature degeneration of the middle 
layer and the tapetum could probably result in the abnormal pollen development and the low fertility of Oncsa. Gower Ramsey.

\section{Literature Cited}

Arends, J.C. 1970. Cytological observations on genome homology in eight interspecific hybrids of Phalaenopsis. Genetica 41:88-100.

Balk, J. and C. Leaver. 2001. The PET-CMS mitochondrial mutation in sunflower is associated with premature programmed cell death and cytochrome c release. Plant Cell 13:1803-1818.

Bolanos-Villegas, V., S.W. Chin, and F.C. Chen. 2008. Meiotic chromosome behavior and capsule setting in Doritaenopsis hybrids. J. Amer. Soc. Hort. Sci. 133:107-116.

Brewbaker, J.L. and B.H. Kwack. 1963. The essential role of calcium ion in pollen germination and pollen tube growth. Amer. J. Bot. 50:859-865.

Chase, M. 1997. The pictorial encyclopedia of Oncidium. Zai Publications. New York, NY.

Conicella, C., G. Genualdo, R. Lucia, K.S. Ramulu, and T. Cardi. 1997. Early tapetal degeneration and meiotic defects are involved in the male sterility of Solanum commersonii (+) S. tuberosum somatic hybrids. Theor. Appl. Genet. 95:609-617.

Felix, L.P. and M. Guerra. 2000. Cytogenetics and cytotaxonomy of some Brazilian species of Cymbidioid orchids. Genet. Mol. Biol. 23: 957-978.

Giuseppina, F., S.D. Angeli, R. Biasi, L. Fattorini, M. Matteucci, A. Canini, and M.M. Altamura. 2013. Tapetum and middle layer control male fertility in Actinidia deliciosa. Ann. Bot. 112:1045-1055.

Goldberg, R.B., T.P. Beals, and P.M. Sanders. 1993. Anther development: Basic principles and practical applications. Plant Cell 5:1217-1229.

Hegde, R.R. and C.K. Rudramuniyappa. 1986. A cytochemical study of pollinium development in Calanthe masuca (Orchidaceae). Cytologia (Tokyo) 51:793-801.

Hieber, A.D., R.G. Mudalige-Jayawickrama, and A.R. Kuehnle. 2006. Color genes in the orchid Oncidium Gower Ramsey: Identification, expression, and potential genetic instability in an interspecific cross. Planta 223:521-531.

Hu, J.R. 2001. Pollen development, pollen viability, fruit set, and seed germination in vitro of Oncidium and allied genera. Master Thesis of Horticulture, National Taiwan University, Taipei, Republic of China.
Jeong, H.J., J.H. Kang, M. Zhao, J.K. Kwon, H.S. Choi, J.H. Bae, H.A. Lee, Y.H. Joung, D. Choi, and B.C. Kang. 2014. Tomato male sterile $10^{35}$ is essential for pollen development and meiosis in anthers. J. Expt. Bot. 65:6693-6709.

Kamemoto, H., T.D. Amore, and A.R. Kuehnle. 1999. Breeding Dendrobium orchids in Hawaii. University of Hawaii Press, Honolulu, HI.

Kapoor, S., A. Kobayashi, and H. Takatsuji. 2002. Silencing of the tapetum-specific Zinc finger gene TAZ1 caused premature degeneration of tapetum and pollen abortion in petunia. Plant Cell 14:2353-2367.

Kim, O.K., J.H. Jung, and C.M. Park. 2010. An Arabidopsis F-box protein regulates tapetum degeneration and pollen maturation during anther development. Planta 232:353-366.

Ku, S., H. Yoon, H.S. Suh, and Y.Y. Chang. 2003. Male-sterility of thermo-sensitive genic malesensitive rice is associated with premature programmed cell death of the tapetum. Planta 217:559-565.

Lee, Y.H. 1987. Cytology and fertility of an intergeneric orchid hybrid. J. Hered. 78:319-322.

Lee, Y.I., F.C. Chang, and M.C. Chung. 2011. Chromosome pairing affinities in interspecific hybrids reflect phylogenetic distances among lady's slipper orchids (Paphiopedilum). Ann. Bot. 108:113-121.

Mizelle, M.B., R. Sethi, M.E. Ashton, and W.A Jemen. 1989. Development of the pollen grain and tapetum of wheat (Triticum aestivum) in untreated plants and plants treated with chemical hybridizing agent RH0007. Sex. Plant Reprod. 2:231-253.

Moir, W.W.G. and M.A. Moir. 1982. Creating Oncidiinae intergenerics. University of Hawaii Press, Honolulu, HI.

Pacini, E. 2010. Relationships between tapetum, loculus and pollen during development. Intl. J. Plant Sci. 171:1-11.

Pacini, E. and M. Hesse. 2002. Types of pollen dispersal units in orchids, and their consequences for germination and fertilization. Ann. Bot. 89:653-664.

Papini, A., S. Mosti, and L. Brighigna. 1999. Programmed-cell-death events during tapetum development of angiosperms. Protoplasma 207:213-221.

Shemesh-Mayer, E., B.M. Tomer, N. Rotem, H.D. Rabinowitch, A.D. Faigenboim, A. Kosmala, D. Perlikowski, A. Sherman, and R. Kamenetsky. 2015. Garlic (Allium sativum L.) fertility: Tran- scriptome and proteome analyses provide insight into flower and pollen development. Front Plant Sci. 6:1-17.

Shi, Y., S. Zhao, and J. Yao. 2009. Premature tapetum degeneration: A major cause of abortive pollen development in photoperiod sensitive genic male sterility in rice. J. Integr. Plant Biol. 51:774-781

Shi, S., D. Ding, S.Y. Mei, and J. Wang. 2010. A comparative light and electron microscopic analysis of microspore and tapetum development in fertile and cytoplasmic male sterile radish. Protoplasma 241:37-49.

Stort, M.N.S. 1984. Sterility barriers of some artificial F1 orchid hybrids: Male sterility. I. Microsporogenesis and pollen germination. Amer. J. Bot. 71:309-318.

Suzuki, K., H. Takeda, T. Tsukaguchi, and Y. Egawa. 2001. Ultrastructural study on degeneration of tapetum in anther of snap bean (Phaseolus vulgaris L.) under heat stress. Sex. Plant Reprod. 13:293-299.

Varnier, A.L., F. Mazeyrat-Gourbeyre, R.S. Sangwan, and C. Clement. 2005. Programmed cell death progressively models the development of anther sporophytic tissues from the tapetum and is triggered in pollen grains during maturation. $\mathrm{J}$. Struct. Biol. 152:118-128.

Vijayaraghavan, M.R., A.K. Shukla, and V. Gupta 1987. Discontinuities in the microsporocyte wall and microsporogenesis in Zeuxine strateumatica (Lindl.). Schltr. J. Orchid Soc. India. 1:19-22.

Wilson, Z.A. and C. Yang. 2004. Plant gametogenesis: Conservation and contrasts in development. Reproduction 128:483-492.

Wu, H. and A.Y. Cheung. 2000. Programmed cell death in plant reproduction. Plant Mol. Biol. 44:267-281.

Yeung, E.C. 1987. Mechanisms of pollen aggregation into pollinia in Epidendrum ibaguense (Orchidaceae). Grana 26:47-52.

Yeung, E.C. and S.J. Blackman. 1983. Floral biology of Epidendrum ibaguense H.B.K. I. Development of the pollinium. Amer. Orchid Soc. Bull. 52:836-840.

Zee, S.Y. and I.H.P. Siu. 1990. Studies on the ontogeny of the pollinium of a massulate orchid (Peristylus spiranthes). Rev. Palaeobot. Palynol. 64:159-164.

Zhang, D., X. Luo, and L. Zhu. 2011. Cytological analysis and genetic control of rice anther development. J. Gen. Genom. 38:379-390. 